\title{
Pengaruh alokasi anggaran sektor pertanian dan industri terhadap PDRB di Kabupaten Kerinci
}

\author{
Raches Aditama*; M. Ridwansyah; Dearmi Artis \\ Prodi Ekonomi Pembangunan, Fak.Ekonomi dan Bisnis, Universitas Jambi \\ *E-mail korespondensi: rachesaditama@gmail.com
}

\begin{abstract}
This study aims to analyze the development of the agricultural and industrial sector budgets and analyze the effect of the farming and industrial sector budget allocations on the GRDP in the Kerinci district. The analytical method used is multiple linear regression with Ordinary Least Square (OLS). This study indicates that the development of the industrial sector budget in Kerinci Regency for the 2010 to 2020 period has fluctuated with an average growth of Rp. 36,920,377,491 per year and the average industrial sector budget in Kerinci Regency for the 2010 to 2020 period is Rp. 8,154,752,012 per year. And the results of the analysis of factors that affect GRDP in Kerinci Regency, simultaneously the agricultural and industrial sector budget variables have a significant effect on GRDP, and partially the industrial sector budget has a significant impact. The farm sector budget has no significant effect.
\end{abstract}

Keywords: GRDP, Agriculture sector budget, Industry sector budget

\begin{abstract}
Abstrak
Penelitian ini bertujuan Untuk menganalisis perkembangan anggaran sektor pertanian dan industri, serta menganalisis pengaruh alokasi anggaran sektor pertanian dan industri terhadap PDRB di kabupaten kerinci. Metode analisis yang digunakan adalah regresi linier berganda dengan Ordinary Least Square (OLS). Hasil dari penelitian ini menunjukan bahwa, perkembangan anggaran sektor industri di Kabupaten Kerinci periode 2010 sampai 2020 mengalami fluktuasi dengan rata-rata perkembangannya Rp. 36.920.377.491 per tahun, dan rata-rata anggaran sektor industri di Kabupaten kerinci periode 2010 sampai 2020 adalah sebesar Rp.8.154.752.012 per tahun. Serta Hasil analisis faktor yang mempengaruhi PDRB di Kabupaten Kerinci, secara simultan variabel anggaran sektor pertanian dan industri berpengaruh signifikan terhadap PDRB dan secara parsial anggaran sektor industri berpengaruh signifikan dan anggaran sektor pertanian tidak berpengaruh signifikan.
\end{abstract}

Kata kunci : PDRB, Anggaran sektor pertanian, Anggaran sektor industri

\section{PENDAHULUAN}

Pertumbuhan ekonomi adalah peningkatan kegiatan ekonomi masyarakat yang menyebabkan kenaikan produksi barang dan jasa atau pendapatan nasional. Pertumbuhan ekonomi dapat diartikan sebagai proses perubahan kondisi perekonomian suatu Negara secara kesinambungan menuju keadaan yang lebih baik selama periode tertentu. Pertumbuhan ekonomi suatu daerah merupakan salah satu unsur utama dalam pembangunan ekonomi regional dan merupakan salah satu indikator makro untuk melihat kinerja perekonomian secara riil di suatu wilayah. Pembangunan ekonomi daerah adalah suatu proses dimana pemerintah daerah dan masyarakatnya mengelola 
setiap sumberdaya yang ada dan membentuk suatu pola kemitraan antara pemerintah daerah dengan sektor swasta untuk menciptakan suatu lapangan kerja baru dan merangsang perkembangan kegiatan ekonomi (pertumbuhan ekonomi) dalam wilayah tersebut.

Salah satu upaya peningkatan perekonomian suatu daerah adalah dengan pendanaan sektor-sektor ekonomi yang ada pada daerah tersebut melalui pengeluaran pemerintah. Pengeluaran pemerintah berfungsi dalam pendanaan pelaksanaan programprogram yang telah dirancang sebuah dinas untuk pembangunan sektor-sektor ekonomi. Program yang dibuat diharapkan dapat membantu pemerintah dalam mengembangkan sektor ekonomi di daerahnya. Program dirancang dan disesuaikan dengan kebutuhan akan suatu wilayahnya daerah perkotaan dan pedesaan (Suwandi, 2013). Sebagai salah satu daerah otonomi Kabupaten Kerinci memiliki potensi sumber daya yang beragam untuk dapat dikembangkan yang tentunya akan dikelola sesuai dengan ketersediaan dan faktor-faktor yang dimiliki. Pemanfaatan dan pengembangan sumber daya dengan baik secara tidak langsung akan meningkatkan laju pertumbuhan ekonomi suatu daerah.

Sampai dengan saat ini sektor pertanian masih tetap menjadi fokus pembangunan di Kabupaten Kerinci mengingat ketahanan pangan merupakan salah satu faktor penentu stabilitas ekonomi sehingga upaya kecukupan pangan menjadi kerangka pembangunan yang mampu mendorong pembangunan sektor lainnya. Alternatif pembangunan sektor pertanian dapat dilakukan dengan melakukan keterpaduan antara sektor pertanian dengan sektor lain yang lebih unggul dalam penciptaan pertumbuhan ekonomi dan memiliki keterkaitan dengan sektor pertanian, yaitu sektor industri pengolahan (Jhingan, 2012) .

Sektor ekonomi memiliki cakupan yang sangat luas sehingga menfokuskan hanya pada 2 subsektornya yaitu sektor pertanian dan industri pengolahan. Sektor pertanian merupakan sektor yang memiliki peran yang cukup besar dalam pertumbuhan perekonomian dilihat pada pembentukan nilai PDRB. Yang merupakan bagian ekonomi rakyat di suatu pedesaan. Kemudian sektor industri merupakan sektor yang memiliki potensi yang besar setelah setor pertanian. Dimana sektor industri yang luas dapat mengambil hasil dari sektor pertanian dan dapat meningkatkan lapangan pekerjaan.

Tabel 1. Pendapatan asli daerah, PDRB dan jumlah penduduk Kabupaten Kerinci

\begin{tabular}{cccc} 
Tahun & $\begin{array}{c}\text { PDRB (Ribu } \\
\text { Rupiah) }\end{array}$ & $\begin{array}{c}\text { Anggaran Sektor } \\
\text { Pertanian (Rupiah) }\end{array}$ & $\begin{array}{c}\text { Anggaran Sektor } \\
\text { Industri (Rupiah) }\end{array}$ \\
\hline 2016 & $3.639 .538,39$ & 36.433 .948 .479 & 7.645 .533 .403 \\
2017 & $3.865 .496,21$ & 39.124 .615 .350 & 9.972 .198 .400 \\
2018 & $4.155 .505,90$ & 32.993 .346 .279 & 9.390 .807 .900 \\
2019 & $4.411 .405,87$ & 46.822 .870 .849 & 12.252 .905 .830 \\
2020 & $4.811 .384,40$ & 39.442 .458 .171 & 8.738 .498 .000 \\
\hline
\end{tabular}

Sumber: BPS dan BPKPD Kabupaten Kerinci 2016 - 2020 (diolah)

Pemerintah berupaya dalam menambah investasi dalam peningkatan pertumbuhan ekonomi di Kabupaten Kerinci. Terlihat dari keseriusan pemerintah dalam anggaran pengeluaran di bidang sektor pertanian dan industri yang diharapakan dapat mengurangi penggangguran dan dapat menambah pertumbuhan ekonomi di Kabupaten Kerinci. Pada tahun 2016 hingga 2020 PDRB, anggaran sektor pertanian dan anggaran sektor industri mengalami fluktusi. Nazara (1997) mengemukakan bahwa pengeluaran pemerintah merupakan variabel yang besarnya diatur sepenuhnya oleh pemerintah sendiri serta dapat mempengaruhi peningkatan faktor-faktor lainnya melalui 
kebijakannya. Dalam konteks inilah, maka permintaan akhir dapat menjadi salah satu alat kebijakan pemerintah. Agar sektor pertanian dapat terus meningkat dan berkembang serta memberikan dampak pada perekonomian suatu daerah khusunya Kabupaten Kerinci maka perlu kontribusi pemerintah dalam pengembangan dan pemberian investasi di sektor pertania, sehingga sektor petanian dapat terus berjalan dan memberikan kesejahteraan kepada masyarakat sekitar dan meningkatkan perekonomian daerah. Dengan adanya pengeluaran pemerintah di sektor pertanian duharapkan dapat memberikan meningkatkan kenaikan outpun yang dapat mempengaruhi pendapatan, kesempatan kerja, serta mendorong tumbuhnya perekonomian. (Anggraeni, 2017)

Anggaran sektor industri yang merupakan pengeluaran pemerintah dibidang ekonomi juga merupakan motor penggerak dalam perekonomian, bukan hanya sektor pertanian sektor industri yang merupakan olahan produk hulu yang akan memberikan perubahan dalam perekonomian tentu perlu pula dorongan dari pemerintah dengan adanya angara-anggaran yang diberikan dalam pengelolaan disektor industri. Semakin tinggi anggaran yang diberikan disektor industri maka perkembangan sektor industri juga akan membaik dapat menyerap tenaga kerja dan memberikan kesejahteraan kepada masyarakat dan meningkatkan pertumbuhan atau pendapatan nasional. (Setyanto, 2018) Dalam pencapaian tujuan pembangunan ekonomi, pemerintah dapat memilih instrumen ekonomi yang akan digunakan untuk mendorong permintaan akhir suatu sektor ekonomi, dan sekaligus melihat bagaimana dampak dari perubahan permintaan akhir tersebut bagi perkembangan sektor ekonomi lainnya. Berdasarkan hal-hal yang telah dipaparkan sebelumnya, maka tujuan penelitian ini adalah 1) mengetahui perkembangan anggaran pertanian dan industri pengolahan di Kabupaten Kerinci, 2) Mengetahui dan Menganalisis Pengaruh Anggaran sektor Pertanian dan Industri terhadap PDRB di Kabupaten Kerinci

\section{METODE}

Penelitian ini menggunakan data sekunder, dalam bentuk regresi berganda. Data sekunder adalah data-data pendukung yang diperoleh dalam bentuk yang sudah jadi atau yang sudah di publikasi oleh pihak pertama yaitu pihak yang mengumpulkan, mengolah dan mempublikasikan data (Syaifuddin, 2007). Data yang digunakan berupa, anggaran sektor pertanian dan industri dari BPKPD Kabupaten Kerinci dan PDRB dari BPS.

Untuk menjawab tujuan pertama digunakan metode analisis deskiptif merupakan suatu analisis secara kualitatif tehadap kondisi dari data-data yang ada untuk memperkuat analisis empirik (Amir, 2009). Untuk menjawab permasalahan kedua yaitu pengaruh alokasi anggaran sektor pertanian dan sektor industri terhadap pertumbuhan ekonomi di Kabupaten Kerinci Tahun 2010-2020, menggunakan analisis regresi berganda dengan model persamaan sebagai berikut (Endri, 2011):

$\mathbf{Y}_{\mathrm{it}}=\boldsymbol{\beta}_{\mathbf{0}}+\boldsymbol{\beta}_{\mathbf{1}} \mathbf{X}_{\mathrm{t}}+\ldots \ldots . . .+\mathbf{u}_{\mathrm{t}}$.

Kemudian diaplikasikan dalam penelitian menjadi:

$\mathbf{P E}_{i t}=\beta_{0}+\beta_{1} A_{S S P}+\beta_{2} A_{S S}+u_{t}$

Dan ditranformasikan dalam bentuk logaritma karena penyesuaian antara PDRB dan nilai anggaran sektor pertanian dan indsutri, sehingga diperoleh:

\section{$\operatorname{LogPDRB}_{i t}=\beta_{0}+\beta_{1} \operatorname{LogASP} P_{t}+\beta_{2} \log A S_{i}+u_{i}$}

Keterangan: 


$\begin{array}{ll}\text { PDRB } & \text { :Pertumbuhan ekonomi } \\ \text { ASP } & \text { :Anggaran sektor pertanian } \\ \text { ASI } & \text { :Anggaran sektor industri } \\ \beta_{0} & \text { :Intersep } \\ \beta_{1}, \beta_{2}, \beta_{3} & \text { :Koefisien regresi } \\ \mathrm{t} & : \text { Tahun }\end{array}$

\section{Uji asumsi klasik}

Berdasarkan hasil regresi, untuk mengambil kesimpulan maka model persamaan harus terbebas dari penyimpangan asumsi klasik. Dalam penelitian ini dikhususkan pada penelaahan gejala normalitas, heteroskedastisitas, autokorelasi dan multikolinearitas.

\section{Uji hipotesis}

Uji hipotesis yang digunakan dalam penelitian ini adalah uji $\mathrm{F}$ (uji simultan) dan Uji $\mathrm{t}$ (uji parsial). Uji Fdigunakan untuk melihat pengaruh variabel berbas secara bersamasama terhadap variabel terikat. Sedangkan uji t digunakan untuk melihat pengaruh masing-masing variabel bebas terhadap variabel terikat.

\section{Koefisien determinasi $\left(\mathbf{R}^{2)}\right.$}

Digunakan untuk mengukur pengaruh variabel independen terhadap variabel dependen. $\mathrm{R}^{2}$ bernilai antara Nol sampai dengan satu $0 \leq \mathrm{R}^{2} \leq 1$ Dapat dihitung dengan rumus sebagai berikut :

$R^{2}=\frac{\sum\left(Y^{\prime}-Y\right)}{\sum(Y i-Y)}$

Dimana:

$\mathrm{R}^{2} \quad=$ Koefisien determinasi

$\mathrm{Y}^{\prime} \quad=$ Determinan

$\mathrm{Y} \quad=$ Industri pengolahan

$\mathrm{Y}_{\mathrm{i}} \quad=$ Rata-rata industri pengolahan

Koefisien determinasi digunakan untuk menggambarkan seberapa besar variabel bebas dapat menjelaskan variabel terikat.

\section{HASIL DAN PEMBAHASAN}

\section{Perkembangan anggaran sektor pertanian}

Sektor pertanian merupakan sektor utama atau penting dalams uatu negara atau daerah khusunya di Kabupaten Kerinci. Sektor pertanian atau bagian dalam sektor ekonomi merupakan penentu dalam kesejahteraan masyarakat. Sebagian besar masyarakat Kabupaten Kerinci bekerja sebagai petani. Sehingga banyak tenaga kerja di Kabupaten Kerinci yang bekerja dibidang pertanian. Sehingga pemerintah perlu memperhatikan dibidang pertanian dengan memberikan anggaran yang optimal untuk di bidang pertanian.

Anggaran sektor pertanian merupakan pengeluaran pemerintah yang dianggarkan atau direncanakan dalam pengembangan sektor pertanian baik di tingkat nasional maupun di tingkat daerah. Anggaran sektor pertanian di Kabupaten Kerinci periode 2006-2020 mengalami fluktuasi walaupun penurunan anggaran yang diberikan 
pemerintah tidak ada yang lebih dari 1 persen. Ini menunjukan bahwa anggaran di sektor pertanian masih tinggi, dibandingkan dengan sektor-sektor lainnya.

Tabel 2. Perkembangan anggaran sektor pertanian Kabupaten Kerinci

\begin{tabular}{ccc}
\hline Tahun & $\begin{array}{c}\text { Anggaran sektor pertanian } \\
\text { (Rupiah) }\end{array}$ & Perkembangan $(\boldsymbol{\%})$ \\
\hline 2006 & 26.199 .080 .293 & - \\
2007 & 31.699 .287 .238 & 0,21 \\
2008 & 25.816 .422 .147 & $-0,19$ \\
2009 & 24.682 .388 .184 & $-0,04$ \\
2010 & 29.448 .474 .803 & 0,19 \\
2011 & 26.660 .363 .375 & $-0,09$ \\
2012 & 33.639 .911 .356 & 0,26 \\
2013 & 40.212 .611 .154 & 0,20 \\
2014 & 41.181 .853 .368 & 0,02 \\
2015 & 40.163 .699 .216 & $-0,02$ \\
2016 & 36.433 .948 .479 & $-0,09$ \\
2017 & 39.124 .615 .350 & 0,07 \\
2018 & 32.993 .346 .279 & $-0,16$ \\
2019 & 46.822 .870 .849 & 0,42 \\
2020 & 39.442 .458 .171 & $-0,16$ \\
\hline Rata-rata & $\mathbf{3 4 . 8 8 0 . 1 6 0 . 7 1 2}$ & $\mathbf{0 , 0 4 4}$ \\
\hline
\end{tabular}

Sumber: BPKAD Kabupaten Kerinci, 2006-2020 (diolah)

Diketahui bahwa Kabupaten Kerinci merupakan Kabupaten di Provinsi Jambi yang rata-rata penduduknya bekerja sebagai petani. Anggaran pertanian yang diberikan merupakan program atau kebijakan yang digunakan untuk memperbaiki kualitas dari pertanian di Kabupaten Kerinci. Pada Periode 2006 sampai 2020 rata-rata anggaran sektor pertanian yang dikeluarkan oleh pemerintah Kabupaten Kerinci adalah sebesar Rp. 34.301.422.017 per tahun dengan rata-rata perkembangannya sebesar 0,044 persen. Pada tahun 2010 anggaran sektor pertanian di Kabupaten Kerinci adalah sebesar Rp. 29.448.474.803 dan turun menjadi Rp. 26.660.363.375 pada tahun 2011 atau turun sebesar 0,19 persen. Peningkatan anggaran sektor pertanian yang dianggarkan oleh pemerintah Kabupaten Kerinci meningkat 0,42 persen pada tahun 2019 dengan anggaran yang disediakan sebesar Rp. 46.822.870.849 namun pada tahun 2020 anggaran yang berikan kembali mengalami penurunan 0,16 persen. Penurunan anggaran ini dikarenakan karena terjadinya devisit anggaran karena terjadinya pandemi di seluruh daerah sehingga anggaran-anggaran yang diberikan untuk sektor mengalami pengurangan.

\section{Perkembangan anggaran sektor industri}

Industri merupakan proses kegiatan pengolahan barang mentah menjadi barang setengah jadi atau barang jadi sehingga memiliki nilai jual yang lebih. Kabupaten Kerinci merupakan satu daerah yang mulai merintis dari besarnya sektor pertanian menjadi sektor industri. Anggaran sektor industri merupakan anggaran untuk bidang ekonomi yang dimanfaatkan untuk kegiatan industri di Kabupaten Kerinci, anggaran ini diharapkan dapat mendorong minat masyarakat kabupaten kerinci yang awalnya bekerja 
di sektor pertanian beralih ke sektor industri yang dapat meningkatkan kesempatan kerja dan menambah kesejahteraan untuk penduduk Kabupaten Kerinci.

Tabel 3. Perkembangan anggaran sektor industri Kabupaten Kerinci

\begin{tabular}{ccc}
\hline Tahun & $\begin{array}{c}\text { Anggaran Sektor Industri } \\
\text { (Rupiah) }\end{array}$ & Perkembangan (\%) \\
\hline 2006 & 2.914 .650 .045 & - \\
2007 & 5.159 .803 .452 & 0,77 \\
2008 & 2.736 .775 .596 & $-0,47$ \\
2009 & 4.326 .299 .886 & 0,58 \\
2010 & 4.160 .989 .595 & $-0,04$ \\
2011 & 4.547 .218 .450 & 0,09 \\
2012 & 5.684 .084 .400 & 0,25 \\
2013 & 7.375 .239 .923 & 0,30 \\
2014 & 8.336 .021 .022 & 0,13 \\
2015 & 11.598 .775 .205 & 0,39 \\
2016 & 7.645 .533 .403 & $-0,34$ \\
2017 & 9.972 .198 .400 & 0,30 \\
2018 & 9.390 .807 .900 & $-0,06$ \\
2019 & 12.252 .905 .830 & 0,30 \\
2020 & 8.738 .498 .000 & $-0,29$ \\
\hline Rata-rata & $\mathbf{7 . 2 8 0 . 3 6 7 . 9 3 3}$ & $\mathbf{0 , 1 3 8}$ \\
\hline
\end{tabular}

Sumber: BPKAD Kabupaten kerinci 2006 - 2020 (diolah)

\section{Pengaruh anggaran sektor pertanian dan anggaran sektor industri terhadap PDRB di Kabupaten Kerinci}

Hasil regresi yang didapatkan dari pengolahan dengan menggunakan e-Views, diperoleh hasil estimasi sebagai berikut:

Tabel 4. Hasil regresi

\begin{tabular}{crrccc}
\hline Variabel & Koefisien & T-statistik & Probabilita & R-squared & $\begin{array}{c}\text { F statistik } \\
\text { (Prob) }\end{array}$ \\
\hline C & 3,504307 & 1,089462 & 0,3077 & & \\
LogASP & $-0,239236$ & $-0,535297$ & 0,6070 & 0,7258 & 10,5902 \\
LogASI & 0,578826 & 2,882647 & 0,0204 & & \\
\hline
\end{tabular}

Sumber. Data diolah, 2021

Dari hasil regres tersebut dapat dirumuskan dalam persamaan berikut:

$\operatorname{LogPDRB}=3,504307-0.239236 \log \mathrm{ASP}+0,578826 \log \mathrm{ASI}$

Keterangan:

PDRB = Produk domestik regional bruto

ASP = Anggaran sektor pertanian

ASI = Anggaran sektor industri

\section{Uji asumsi klasik}

Hasil uji Normalitas berdasarkan hasil JB diperoleh bahwa nilai JB lebih kecil dari pada $\mathrm{X}^{2}$ Tabel $(0,59<19,67)$, sehingga dapat disimpulkan data berdistribusi normal. Berdasarkan hasil uji Heterokedastisitas Obs*R-squared $<\mathrm{X}^{2}$ tabel $(1,36<$ 19,67) dapat disimpulkan bahwa data tidak terdapat masalah heterokedastisitas. Uji 
Autokorelasi Nilai Obs ${ }^{*} \mathrm{R}-$ Squared lebih kecil dari $\mathrm{X}^{2}$ tabel $(1,97<19,67)$, maka $\mathrm{H}_{1}$ diterima dan $\mathrm{H}_{0}$ ditolak, kesimpulannya adalah dengan tingkat keyakinan 95 persen, dapat dikatakan bahwa tidak terdapat autokorelasi dalam model regresi.Dari hasil uji asumsi klasik tersebut dapat disimpulkan bahwa penelitian ini terbebas dari asumsi klasi dan bersifat BLUE (Best, Linear, Unbiased, Estimator).

Tabel 5. Hasil asumsi klasik

\begin{tabular}{cccc}
\hline Uji asumsi klasik & $\begin{array}{c}\text { JB/ Obs*R- } \\
\text { Squared }\end{array}$ & $\mathbf{X}^{\mathbf{2}}$ Tabel & Kesimpulan \\
\hline Normalitas & 0,52 & & $\begin{array}{c}\text { Error term } \text { berdistribusi } \\
\text { normal } \\
\text { Heterokedastisitas }\end{array}$ \\
Autokorelasi & 2,69 & 26,29 & $\begin{array}{c}\text { Tidak terdapat } \\
\text { heterokedastisitas } \\
\text { Tidak terdapat autokorelas }\end{array}$ \\
\hline
\end{tabular}

Sumber. Data diolah, 2021

\section{Pengujian hipotesis}

\section{Uji F (uji simultan)}

Dari hasil ouput analisis regresi dapat diketahui nilai $\mathrm{F}$ hitung yaitu sebesar 10,5902 dengan probabilitas $\mathrm{F}$ sebesar 0.0056 atau lebih besar dari $\alpha$ pada taraf $=0,05$ (5\%) dalam hal ini Fhitung > Ftabel (F hitung 10,5902 > F tabel 3,34) yang artinya semua variabel bebas secara bersama-sama mempunyai pengaruh terhadap variabel terikat. Dapat disimpulkan bahwa adanya keterkaitan antara variabel bebas anggaran sektor pertanian dan anggaran sektor industru secara bersama-sama terhadap variabel terikat PDRB dalam tingkat signifikansi 5 persen.

\section{Uji t (uji parsial)}

Nilai Constanta sebesar 3,5043, artinya apabila semua variabel bebas (anggaran sektor pertanian dan anggaran sektor industri) memiliki nilai 0 atau tidak ada pengaruhnya maka PDRB di kabupaten kerinci meningkat sebesar 3,5043 persen.

Anggaran sektor pertanian tidak berpengaruh terhadap pertumbuhan ekonomi di Kabupaten Kerinci. Berdasarkan perbandingan nilai dari t-hitung dan t-tabel. T-hitung yang diperoleh nilainya lebih kecil dari pada nilai t-tabel $(0,5352<1,79)$ serta probabilita dari variabel PDRB yang didapatkan 0,6070 yang lebih besar dari 0,05 tingkat alfa signifikansi. Artinya secara parsial anggaran sektor pertanian tidak berpengaruh terhadap PDRB.

Anggaran sektor industri berpengaruh signifikan terhadap pertumbuhan ekonomi di Kabupaten Kerinci. t-hitung yang diperoleh dari hasil output regresi memiliki nilai yang lebih besar dari t-tabel. $(2,8826>1,79)$ serta nilai probabilita dari variabel jumlah tenaga kerja yang lebih kecil dari tingkat signifikansi alfa 5 persen. $(0,0204>0,05)$. Artinya secara parsial Anggaran sektor industri berpengaruh signifikan terhadap pertumbuhan ekonomi. Yang artinya apabila anggaran sektor industri naik 1 persen maka PDRB kabupaten Kerinci juga mengalami peningkatan sebesar 0,58 persen.

\section{Koefisien determinasi $\left(\mathbf{R}^{2}\right)$}

Analisis determinasi dalam regresi linier berganda digunakan untuk mengetahui persentase sumbangan pengaruh variabel independen secara serentak terhadap variabel dependen. Berdasarkan tabel 5.3 Didapatkan hasil $\mathrm{R}^{2}$ sebesar 0,7258 atau sebesar 72,58 persen. Hal ini menunjukan bahwa kemampuan variabel anggaran sektor pertanian dan 
anggaran sektor industri dalam menjelaskan variabel PDRB sebesar 72,58 persen sedangkan sisanya sebesar 27,42 persen dijelaskan oleh variabel lain yang tidak diteliti atau dijelaskan dalam penelitian ini.

\section{Interpretasi secara ekonomi \\ Pengaruh anggaran sektor pertanian terhadap PDRB}

Berdasarkan hasil pengolahan diperoleh bahwa anggaran sektor pertanian tidak memiliki pengaruh yang signifikan terhadap PDRB di Kabupaten Kerinci. Anggaran yang diberikan untuk sektor pertanian belum memberikan peran dalam perekonomian di Kabupaten Kerinci. Sebagaimana tujuan dari adanya anggaran ini adalah untuk memberikan kesejahteraan kepada petani seperti penyediaan benih unggul, alat mesin pertanian, pupuk, dan ketersedian irigasi (Kementan, 2021). Salah satu contoh dalam anggaran pertanian di Kabupaten Kerinci yaitu pemberian subsidi pupuk kepada petani. Namun petani di Kabupaten Kerinci masih banyak yang belum merasakan langsung pupuk bersubsidi yang disediakan dari anggaran-anggaran yang telah diberikan tersebut. Selain itu dalam segi harga petani di Kabupaten Kerinci masih belum stabil, sehingga Anggaran yang diberikan tidak memiliki pengaruh langsung terhadap PDRB atau pertumbuhan ekonomi di Kabupaten Kerinci. Selain itu kualitas SDM pertanian atau dapat dikatakan sebagai petani, rata-rata tingkat pendidikan petani masih dalam kategori rendah, hal ini menghambat dalam penggunaan dan pemanfaatan tekonologi sebagai inovasi baru yang dapat memperbaiki pertanian di Kabupaten Kerinci. Sehingga perlu upaya peningkatan kemampuan dan skill petani melalui pelatihan dan pembinaanpembinaan keterampilan bagi petani, sehingga anggaran yang diberikan dapat memberikan dampak yang baik bagi petani maupun daerah Kabupaten Kerinci itu sendiri.

\section{Pengaruh anggaran sektor industri terhadap PDRB}

Industri di Kabupaten Kerinci sebagian besarnya adalah industri rumah tangga atau industri yang dikatakan masih dalam level kecil-menengah. Sehingga peran pemerintah sangat dibutuhkan dalam perkembangan industri ini. Pengeluaran pemerintah yang telah diprogramkan untuk industri di Kabupaten Kerinci memberikan dampak yang positif bagi masyarakat Kabupaten Kerinci. Hal ini sesuai dengan penelitian yang dilakukan oleh Sitaniapessy (2013), yang menyatakan bahwa pengeluaran pemerintah sektor perindustrian dan perdagangan berpengaruh yang signifikan terhadap PDRB di Maluku Tengah.

Pengaruh yang positif pada anggaran sektor industri dikarenakan sektor industri memiliki peran vital dalam roda penggerak perekonomian dengan adanya keunggulankeunggulan yang ada di sektor industri dibandingkan dengan sektor-sektor lainya. Seperti alokasi yang dikeluarkan adalah program bantuan atau pinjaman dana untuk proses produksi suatu industri dan kegiatan penyuluhan yang diberikan juga memberikan tambahan ilmu untuk para pelaku industri agar kegiatan industrinya tetap berjalan dengan baik dan lancar. Dengan adanya keunggulan dari sektor industri seperti besarnya dalam penyerapan tenaga kerja, modal yang mendukung, serta kemampuan dalam menciptakan produk yang memiliki value added dari setiap pengolahan. Selain itu program perubahan dari masyarakat pertanian menuju masyarakat industri dari pemerintah kini juga semakin dirasakan, banyak petani yang tidak hanya menjual bahan mentah tetapi pada saat ini diolah lagi agar mendapatkan nilai tambah.

Dengan adanya pembangunan di sektor industri atau dengan ditambahankan alokasi anggaran pada sektor industri tentu dapat mendorong perekonomian, yang dapat 
memacu sektor-sektor lainnya seperti sektor pertanian. Sektor pertanian sebagai penyedia bahan-bahan baku dan industri yang mengelola bahan baku menjadi bahan yang memiliki nilai tambah. Sehingga alokasi anggaran sektor industri sangat berpengaruh terhadap kemajuan industri di Kabupaten Kerinci dan berdampak pula pada perekonomian di Kabupaten Kerinci atau PDRB Kabupaten Kerinci.

\section{KESIMPULAN DAN SARAN}

\section{Kesimpulan}

Perkembangan anggaran sektor pertanian di Kabupaten Kerinci mengalami fluktuasi Rp. 34.880.160.712 per tahun dengan rata-rata perkembanganya sebesar 0,032 persen., Perkembangan anggaran sektor industru di Kabupaten Kerinci mengalami fluktuasi dengan rata-rata anggaran sektor industri di Kabupaten adalah sebesar Rp. 7.280.367.933 per tahun dengan rata-rata perkembangannya sebesar 0,089 persen.

Hasil analisis faktor yang mempengaruhi PDRB di Kabupaten Kerinci, anggaran sektor pertanian dan anggaran sektor industri secara bersama-sama berpengaruh signifikan terhadap PDRB di Kabupaten Kerinci. Secara parsial anggaran sektor pertanian tidak berpengaruh signifikan dan anggaran sektor industri berpengaruh signifikan.

\section{Saran}

Kepada Pemerintah Kabupaten Kerinci diharapakan dapat memaksimalkan anggaran yang dialokasikan terutama untuk sektor pertanian agar petani dapat memanfaatkan alokasi anggaran dengan baik dan dapat memberikan kesejahteraan terutama masyarakat sekitar. Dan dapat meningkatkan alokasi anggaran sektor industri agar sektor industri di Kabupaten Kerinci dapat terus berkembang bahkan tidak hanya industri kecil saja tetapi juga industri sedang dan besar.

Kepada peneliti selanjutnya diharapkan menambahkan variabel-variabel lainya sehingga dapat lebih mendetail dalam memberikan kontribusi terhadap PDRB di Kabupaten Kerinci.

\section{DAFTAR PUSTAKA}

Amir, A dkk. (2009). Meodologi penelitian ekonomi dan penerapannya. IPB Press: Bogor

Anggraeni, M. (2017). Analisis pengaruh pengeluaran pemerintah di sektor pendidikan, kesehatan, dan pertanian terhadap pertumbuhan ekonomi indonesia periode 1970-2015. Skripsi . Universitas Negeri Yogyakarta.

Badan Pusat Statistik Kabupaten Kerinci. (2018). Data produk domestik bruto regional menurut lapangan usaha tahun 2010-2018. Diakses dalam http://www.bps.go.id . Tanggal 15 Maret 2019, Pukul 12.00 WIB.

Jhingan, M.L. (2012). Ekonomi pembangunan dan perencanaan. PT Raja Grafindo Persada: Jakarta.

Nazara, S. (1997). Analisis input output. Fakultas Ekonomi Universitas Indonesia: Jakarta.

P Parmadi, E Emilia, Z Zulgani.(2018). Daya saing produk unggulan sektor pertanian Indonesia dalam hubungannya dengan pertumbuhan Ekonomi, Jurnal Paradigma Ekonomika, 13 (2), 77-86 
Setyanto, Kurniawan dkk. (2018). Analisis dampak peningkatan alokasi anggaran pada sektor industri makanan dan minuman terhadap pembangunan ekonomi Jawa Tengah. Jurnal Manajemen Pembangunan Daerah. 10, 33-45.

Sitaniapessy, Harry. (2013). Pengaruh pengeluaran pemerintah terhadap PDRB dan PAD. Jurnal Economia, 9(1), 38-51.

Suwandi \& Edy. (2013). Analisis pengaruh pengeluaran pemerintah untuk sektor pertanian terhadap PDRB sektor pertanian 35 Kabupaten/Kota di Provinsi Jawa Tengah 2007-2010. Diponogoro Journal of Economics. 2(4), 1-10

Y Yulmardi, E Erfit.(2018). Daya saing sektor pertanian dalam mendorong pembangunan pertanian di Provinsi Jambi, Jurnal Paradigma Ekonomika 13 (2), 65-76 